Volume 11, Nomor 2, November 2019, pp 262-275 Copyright (C) 2017 Jurnal Akuntansi Maranatha, Program Studi Akuntansi, Fakultas Ekonomi, Universitas Kristen Maranatha. ISSN 2085-8698 | e-ISSN 2598-4977. http://journal.maranatha.edu

\title{
Analisis Faktor yang Mempengaruhi Penggunaan Instrumen Derivatif Valuta Asing sebagai Pengambilan Keputusan Hedging (Studi pada Perusahaan Manufaktur Sub Sektor Automotive and Allied Products yang terdaftar di BEI Periode 2011-2017)
}

\author{
Ivonne Bonita \\ Fakultas Ekonomi Program Studi Magister Manajemen-Univ.Katolik Parahyangan \\ (Jl. Merdeka No. 30, Bandung) \\ ivonne.bonita11@gmail.com
}

\begin{abstract}
This paper aims to examine the effect of the variable debt equity ratio (DER), financial distress, growth opportunity, liquidity and firm size on the use of derivative instruments as a means of taking hedging decisions. The population and sample of the company are classified as automotive and allied products sub sector manufacturing companies with annual data obtained from the Indonesia Stock Exchange in the period 2011 to 2017, based on the Indonesia Capital Market Directory 2015. To obtain valid research results, the sampling technique used in the study is a purposive sampling method. Hypothesis testing uses a logistic regression model.
\end{abstract}

Keywords: Hedging, DER, Financial Distress, Firm Size, Logistic Regression

\section{Pendahuluan}

Akibat globalisasi maka perdagangan internasional menjadi sangat mudah dilakukan. Namun dalam prakteknya ada risiko yang selalu melekat pada proses perdagangan internasional. Di dalam perdagangan internasional tidak bisa dipungkiri bahwa akan terjadi sebuah transaksi internasional dimana sudah pasti melibatkan pertukaran mata uang asing, sedangkan nilai tukar mata uang asing selalu berfluktuasi. Maka dari itu hal ini menjadi sorotan utama risiko yang dapat terjadi akibat perdagangan internasional.

Permasalahan yang menyangkut perubahan nilai tukar mata uang asing sangat signifikan dapat dipengaruhi oleh banyak aspek, mulai dari kondisi pemerintahan, perubahan regulasi, kebijakan pemerintah dan sebagainya. Bahkan nilai tukar mata uang asing juga dapat disebabkan oleh perekonomian yang terjadi bukan dari negara yang 
bersangkutan, pengaruh kondisi perekonomian atau pemerintahan negara asing pun dapat mempengaruhi kondisi nilai mata uang negara lain dalam hal ini adalah Indonesia.

Adapun contoh isu yang terjadi dewasa ini yang nyata dan mempengaruhi nilai tukar mata uang Indonesia. Berdasarkan berita BBC.com, pada tahun 2016 lalu, tengah ramai dibicarakan tentang sikap Inggris yang ingin memisahkan diri dari Uni Eropa atau dikenal dengan Brexit (British Exit). Dengan adanya permasalahan dan atau isu ini, tentu saja membuat seluruh dunia termasuk Indonesia mengalami kekhawatiran mengenai perekonomiannya di masing-masing negara yang akan berdampak dari kasus ini karena Inggris menjadi salah satu pusat perekonomian Eropa dan dunia. Menurut gubernur Bank Indonesia, dampak itu akan terlihat pada pasar keuangan, namun tidak memiliki hubungan langsung baik dari pihak Inggris maupun Indonesia hanya saja pada saat penutupan perdagangan pada hari Jumat 24 Juni 2016 sore, IHSG sempat melemah 39,74 poin atau sebesar $0,82 \%$ ke level Rp4.834,57. Adapun kurs rupiah melemah $1,08 \%$ ke posisi Rp13.391 per dolar AS. Menurut Komisaris Independen Bank Mandiri, Goei Siauw Hong, Beliau mengatakan bahwa "Secara nilai mata uang dampak jangka pendek itu akan ada di aset safe heaven (aset yang nilainya cenderung tetap walau terjadi gejolak pasar, seperti emas dan dolar Amerika), sehingga mengakibatkan menguatnya mata uang dolar Amerika terhadap hampir sebagian besar nilai mata uang yang ada di dunia, tetapi rupiah justru sedikit melemah". Sementara itu menurut analis senior BCA David Sumual mengatakan bahwa "Pemerintah Indonesia dapat melindungi perekonomian Indonesia dengan cara melakukan swap arrangement (peminjaman kurs asing) dengan bank-bank sentral lain serta membuat anggaran yang konservatif karena risiko global yang masih relatif tinggi”.
Menguatkan kasus Brexit, menurut berita di Bloomberg.com, nilai tukar rupiah hampir melemah sebesar 3\% terhadap dolar Amerika Serikat sejak akhir bulan Januari dan menyentuh dua tahun terendah sebagai mata uang yang mempunyai kinerja buruk di Asia. Gubernur Bank Indonesia mengatakan bahwa Bank Indonesia tidak akan terganggu oleh penurunan cadangan devisa nya, dan telah memperkirakan beberapa kemungkinan volatilitas pasar yang akan terjadi.

Ekonomi terbesar di Asia Tenggara sedang berjuang untuk bertahan. Pertumbuhan ekonomi terjebak di kisaran 5\% dan berpotensi melambat pada kuartal pertama tahun ini, sementara kegiatan pinjaman tetap lemah dan di bawah perkiraan bank sentral. Tingkat inflasi berada di level terendah selama 14 bulan dari $3.2 \%$ pada bulan Februari, Bank Indonesia mempertahankan kisaran perkiraan untuk tahun ini di $2.5 \%$ menjadi $4.5 \%$.

Selain kasus Brexit, pemilihan umum presiden Amerika Serikat antara Donald Trump dan Hillary Clinton juga memiliki dampak yang sangat signifikan terhadap perekonomian Indonesia. Menurut Merdeka.com, "Donald Trump berhasil mengalahkan Hillary Clinton turut membawa dampak bagi perekonomian dunia. Salah satunya adalah berdampak pada negara Indonesia”. Ketua umum Himpunan Pengusaha Muda Indonesia, Bahlil Lahadila memperkirakan pelemahan rupiah akan terus berlanjut. Kenapa?, karena selama ini investor menaruh harapan besar pada calon presiden Hillary Clinton dalam memenangi pemilu di Amerika Serikat. Dan menurut BBC.com alasan Indonesia menolak Trump adalah kebijakan perdagangannya yang anti perdagangan bebas untuk melindungi industri dalam negeri AS, sementara Clinton dianggap lebih terbuka dibanding Trump akan membatasi ekspor dari negara lain.

Berdasarkan berita cnnindonesia.com, selepas Februari 2018, nilai tukar rupiah 
tergolek lesu di kisaran Rp13.700 per dolar AS. Sentimen menjelang pengumuman suku bunga acuan bank sentral AS Federal Reserve (The Fed) kala itu diyakini sebagai penyebab utama. Dalam pidatonya 27 Februari lalu, Gubernur The Fed Jerome Powell memberi sinyal tegas terkait rencana menaikkan suku bunga (fed rate) sebanyak tiga kali tahun ini. Hal itu membawa kekhawatiran bahwa investor yang berada di Indonesia akan memindahkan dananya ke pusat investasi dunia tersebut dan 'memukul' nilai tukar rupiah. Sebelum The Fed benar-benar mengumumkan fed rate, Bank Indonesia (BI) rupanya beraksi sigap dengan melakukan intervensi rupiah melalui guyuran cadangan devisa (cadev) ke pasar keuangan. Sayangnya, cadev yang digelontorkan saat itu belum terlalu besar hingga tak mampu mendongkrak rupiah secara signifikan. Ekonom dari Institute Banking School (IBS) Batara Simatupang menilai, "Setidaknya BI masih bisa menahan suku bunganya hingga ada kepastian suku bunga acuan The Fed yang dipastikan masih akan naik lagi dalam beberapa bulan ke depan. Lalu, inflasi. Nilai tukar rupiah bisa kian 'ambles' bila inflasi meningkat". Menurut Batara, "Inflasi sendiri memang akan meningkat dalam beberapa waktu ini. Pasalnya, harga Bahan Bakar Minyak (BBM) baru saja mengalami perubahan, misalnya Pertalite yang dinaikkan sebesar Rp200 per liter pada akhir pekan kemarin".

Berdasarkan isu-isu tersebut maka setiap perdagangan internasional sangat diwajibkan untuk melakukan antisipasi risiko. Salah satu caranya yaitu dengan hedging (lindung nilai). Aktivitas hedging dapat dilakukan dengan menggunakan instrumen derivatif. Dalam pengaplikasian instrumen derivatif, terdapat faktor-faktor yang mempengaruhi perusahaan dalam menggunakan hedging. Alasan yang mendasar mengapa setiap perusahaan belum tentu menggunakan hedging adalah karena dewasa ini semua yang ingin dicapai pasti memerlukan pengorbanan, begitu juga dengan hedging. Dalam meminimalisir risiko transaksi valuta asing, sebuah perusahaan harus mengeluarkan biaya. Biaya ini disebut biaya akibat melakukan hedging. Oleh karena itu perusahaan harus menilai aspek internal perusahaan apa yang sangat mempengaruhi keputusan dalam melakukan hedging.

Pengelolaan hedging sangat transaksional, jelas karena melakukan hedging menyebabkan biaya. Maka dari itu perlunya penelitian lebih lanjut mengenai faktor-faktor yang dapat mempengaruhi pengambilan keputusan penggunaan hedging. Putro (2012) mengkaji faktorfaktor yang dapat mempengaruhi pengambilan keputusan hedging pada industri manufaktur sub sektor automotive and allied product periode 2006 hingga 2010 mendapatkan hasil penelitian yaitu DER, growth opportunity dan firm size berpengaruh signifikan dan positif terhadap pengambilan keputusan hedging sedangkan financial distress dan liquidity tidak berpengaruh terhadap pengambilan keputusan hedging.

Berdasarkan hasil penelitian Putro (2012), dengan melihat isu-isu mengenai mudahnya suatu nilai tukar mata uang berubah inilah yang melatarbelakangi penelitian ini dibuat. Penulis ingin mengetahui faktor-faktor apa yang mempengaruhi pengambilan keputusan hedging di sektor yang sama dengan peneliti Putro (2012) dengan melakukan pembaharuan terhadap rentang waktu sehingga didapat judul penelitian yaitu Keputusan hedging dalam Industri Manufaktur periode 2011-2017 dengan menggunakan Logistic Regression. 


\section{Kerangka Teoritis dan Hipotesis}

\section{Debt Equity Ratio}

Debt to equity ratio merupakan salah satu rasio keuangan yang tergolong kelompok rasio solvabilitas. Menurut Sundjaja dkk (2012:188), debt to equity ratio atau disebut juga sebagai rasio utang terhadap ekuitas adalah perbandingan antara utang jangka panjang dengan modal pemegang saham perusahaan. Dapat diartikan bahwa hasil persentase dari rumus $D E R$ ini adalah pinjaman jangka panjang perusahaan sebesar sekian persen (didapat dari olahan rumus $D E R$ ) dari modal sendiri. Semakin tinggi $D E R$ menunjukkan komposisi utang jangka panjang semakin besar dibanding dengan total modal sendiri, sehingga berdampak semakin besar beban perusahaan terhadap pihak luar (kreditur).

$$
\text { Debt to Equity Ratio }=\frac{\text { Total Liabilities }}{\text { Total Equity }}
$$

Dalam penelitian yang dilakukan Putro (2012) dan Zulfiana (2014) variabel DER berpengaruh positif terhadap keputusan hedging. Menurut Zulfiana (2014:93) yang menyimpulkan dari penelitian terdahulu hal ini terjadi dikarenakan semakin tinggi tingkat hutang atau debt equity ratio maka akan semakin besar pengambilan keputusan hedging yang dilakukan untuk mengurangi dampak buruk dari risiko hutang. DER atau debt equity ratio, menurut Kasmir (2008:157), "merupakan rasio yang digunakan untuk menilai hutang dengan ekuitas". DER untuk setiap perusahaan tentu akan berbeda-beda tergantung pada karakteristik bisnis dan keberadaan arus kasnya. Perusahaan yang memiliki arus kas yang stabil cenderung memiliki rasio DER yang lebih tinggi dibandingkan dengan perusahaan dengan rasio kas yang kurang stabil.

\section{Financial Distress}

Financial Distress digunakan untuk mengukur suatu indikasi kesulitan dalam pengembalian hutang kepada kreditur, atau dapat disebut sebagai pengukur kebangkrutan perusahaan. Menurut Sundjaja dkk (2012:223), kepailitan suatu perusahaan tidak terjadi secara mendadak, tetapi dimulai dari kesulitan keuangan terlebih dahulu sebagai pertanda akan terjadinya suatu kepailitan perusahaan. Kemampuan untuk memprediksi kepailitan perusahaan dalam waktu dekat adalah penting bagi para calon kreditur dan investor. Salah satu cara mengukur financial distress adalah dengan perhitungan Z-score yang dikemukakan Altman1968. Menurut Brealey dkk (2012:565), financial distress diformulasikan dengan metode Z-Score sebagai berikut:

$$
\begin{gathered}
Z \text {-Score }=3.3 \times \frac{E B I T}{\text { Total assets }}+1.0 \times \\
\frac{\text { sales }}{\text { total assets }}+0.6 \times \frac{\text { market value of equity }}{\text { total book debt }}+ \\
1.4 \times \frac{\text { retained earnings }}{\text { total assets }}+1.2 \times \frac{\text { working capital }}{\text { total assets }}
\end{gathered}
$$

Dalam penelitian yang dilakukan Putro (2012) dan Zulfiana (2014) variabel financial distress tidak berpengaruh terhadap keputusan hedging. Zulfiana (2014) yang didukung oleh penelitian Triki (2005) dan Guniarti (2011) dalam Zulfiana (2014:95), menyatakan bahwa "Ketika nilai Z-score Altman menurun, perusahaan akan terdorong untuk melakukan keputusan hedging sehingga dapat diketahui bahwa hubungan antara nilai Z-score Altman dengan keputusan hedging adalah berhubungan negatif'. Lanjut menurut Zulfiana (2014), "Hal ini dikarenakan pengambilan keputusan hedging yang dilakukan pada saat perusahaan mengalami risiko financial distress sedangkan pada saat perusahaan tidak mengalami kesulitan keuangan maka tidak mengambil keputusan hedging". Maka dapat disimpulkan berdasarkan hasil penelitian terdahulu, sebagian perusahaan melakukan keputusan 
hedging bukan untuk mengantisipasi risiko tetapi dilakukan ketika risiko itu sudah berubah menjadi masalah. Padahal menurut Smith and Stulz (1985) berpendapat bahwa, "Hedging can reduce the probability that a firm will go bankrupt and thereby reduce the expected costs of financial distress".

\section{Growth Opportunity}

Wiyono dan Kusuma (2017:405), mengatakan underinvestment hypothesis memprediksi hubungan yang positif antara growth opportunities dan penggunaan derivatif (hedging). Underinvestment umurnya akan dihadapi oleh perusahaan yang memiliki growth opportunities yang lebih besar sehingga meningkatkan motivasi perusahaan untuk melakukan hedging. Kesempatan pertumbuhan perusahaan yang tinggi akan menunjukkan nilai pasar yang semakin tinggi diantara perusahaan lain. Akibat dari pertumbuhan perusahaan yang tinggi dan nilai pasar ikut tinggi maka tidak jarang investor bersedia menanamkan dananya kepada perusahaan yang memiliki kemampuan tersebut, karena dinilai akan menjadi sarana investasi yang baik. Pertumbuhan perusahaan adalah perbandingan antara MVE (Market Value of Equity) dan BVE (Book Value of Equity). Secara sistematis dapat diformulasikan sebagai berikut:

Growth opportunity $=\frac{\text { Market value of equity }}{\text { Book value of equity }}$

Dimana:

$$
\begin{gathered}
\text { Market value of equity }=\frac{\text { Earning After Tax }}{\text { Earning Per Shares }} \\
\text { x Closing Price } \\
\text { Book value of equity }=\text { Total Assets }- \text { Total } \\
\text { Liabilities }
\end{gathered}
$$

Peneltian terdahulu yang dilakukan oleh Putro (2012) dan Subagja (2015) menemukan hasil dari penelitian yang telah dilakukan bahwa growth opportunity berpengaruh positif terhadap keputusan hedging. Sedangkan hasil dari penelitian yang dilakukan Zulfiana (2014) menyatakan bahwa growth opportunity tidak berpengaruh positif terhadap keputusan hedging karena untuk mengatasi pertumbuhan laba perusahaan agar semakin tinggi dapat menggunakan berbagai cara yang sifatnya luas.

Menurut Putro (2012:34), growth opportunity yang tinggi menunjukkan peluang perusahaan untuk maju kian besar, sehingga untuk menjawab kesempatan tersebut, kebutuhan dana dalam jumlah yang cukup besar untuk membiayai pertumbuhan tersebut di masa yang akan datang akan sangat dibutuhkan.

$$
\text { Pramborg (2005) dalam }
$$

penelitiannya menyatakan, Theoretical findings suggest that hedging reduces the incentive to underinvest (see Myers, 1977; Bessembinder, 1991). Because firms with more valuable growth opportunities are more likely to be affected by the under investment problem, these firms may be more likely to hedge. The proxy for growth opportunities is the book-to-market ratio. A lower value of this proxy variable suggests more valuable growth opportunities.

\section{Liquidity}

Menurut Sundjaja dkk (2012:179), likuiditas digunakan untuk mengetahui kemampuan perusahaan dalam memenuhi kewajiban jangka pendeknya yang jatuh tempo. Tingkat likuiditas menunjukkan kemampuan suatu perusahaan dalam memenuhi kewajiban pada saat ditagih. Perusahaan yang mampu melunasi kewajibannya tepat waktu berarti perusahaan tersebut dikatakan dalam keadaan likuid.

$$
\text { Current Ratio }=\frac{\text { Current Assets }}{\text { Current Liabilities }}
$$

Putro (2012) dan Subagja (2015) dalam penelitiannya menyatakan bahwa variabel liquidity tidak berpengaruh terhadap pengambilan keputusan hedging. 
Menurut Kasmir (2008:135), dari hasil pengukuran rasio, apabila rasio lancar rendah, dapat dikatakan bahwa perusahaan kurang modal untuk membayar utang. Namun, apabila hasil pengukuran rasio tinggi, belum tentu kondisi perusahaan sedang baik. Hal ini dapat saja terjadi karena kas tidak digunakan sebaik mungkin.

Pramborg (2005) dalam penelitiannya menyatakan, Hedging could increase the value of the firm by lowering the expected costs of financial distress (see Smith and Stulz, 1985). Nance et al. (1993) hypothesized that the probability of encountering financial distress may be reduced by maintaining more liquid assets, thereby reducing the need to hedge. The proxy for liquidity is the current ratio.

\section{Firm Size}

Ukuran perusahaan sangatlah berpengaruh terhadap keputusan maupun strategi yang diambil. Semakin besar perusahaan maka semakin besar pula risiko yang dihadapi.

\section{Firm Size $=$ Ln(Total Assets $)$}

Putro (2012) dan Zulfiana (2014) memiliki hasil penelitian bahwa firm size berpengaruh positif terhadap pengambilan keputusan hedging. Menurut Zulfiana (2014:99), dampak yang ditimbulkan suatu risiko dalam perusahaan skala besar lebih berdampak besar, maka mereka akan memberlakukan suatu manajemen risiko yang lebih ketat dibandingkan perusahaan kecil. Dan keputusan hedging yang dilakukan perusahaan adalah untuk mengantisipasi terjadinya risiko operasional, karena perusahaan yang memiliki ukuran yang besar memiliki aktivitas operasional yang luas dan lebih berisiko karena adanya kemungkinan besar untuk bertransaksi ke berbagai negara akan melibatkan beberapa mata uang berbeda. Dalam kegiatannya akan terdapat eksposur transaksi karena fluktuatifnya nilai tukar mata uang asing.

\section{Model Penelitian Dan Pengembangan Hipotesis}

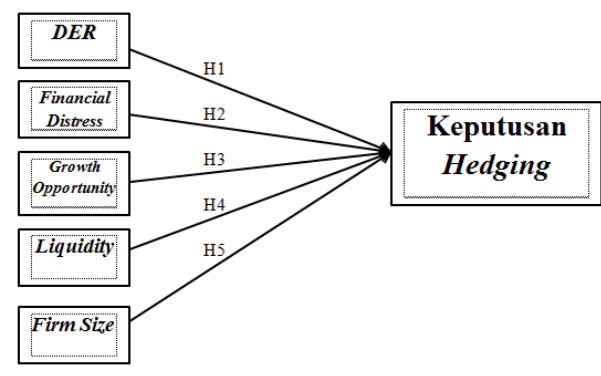

\section{Gambar 1 \\ Model Penelitian}

H1 : Terdapat pengaruh signifikan DER terhadap keputusan hedging

$\mathrm{H} 2$ : Terdapat pengaruh signifikan financial distress terhadap keputusan hedging

H3 : Terdapat pengaruh signifikan growth opportunity terhadap keputusan hedging

H4 : Terdapat pengaruh signifikan liquidity terhadap keputusan hedging

H5 : Terdapat pengaruh signifikan firm size terhadap keputusan hedging

\section{Metode Penelitian}

Metode penelitian yang dilakukan dalam penulisan ini adalah mengumpulkan data laporan keuangan tahunan periode 2011 hingga 2017 yang berasal dari website idx.co.id. Perusahaan dalam penelitian ini yakni, Astra Internasional, Astra Otoparts, Gajah Tunggal, Indomobil Sukses Internasional, Indospring, Intraco Penta, Nipress, Selamat Sempurna, Tunas Ridean dan United Tractors. Total aset, total hutang, pasiva lancar, aset lancar, pendapatan, dan sebagainya menjadi dasar perhitungan masing-masing variabel yang digunakan yaitu debt equity ratio, financial distress, growth opportunity, liquidity dan firm size. Kemudian data dirangkum 
berdasarkan tahun untuk diolah menggunakan aplikasi SPSS untuk mengetahui nilai dari statistik deskriptifnya dan menganalisa data dengan menggunakan regresi logistik karena variabel dependen berupa skala nominal $(1=$ menggunakan hedging dan $0=$ tidak menggunakan hedging), dengan menggunakan regresi logistik ini terhadap 6 variabel, data akan diuji dan dinilai kelayakan model regresi, dinilai keseluruhan model, menguji koefisien regresi, menilai model summary dan menilai model statistik dari koefisien regresi sehingga output simpulan mampu menjawab rumusan masalah.

\section{Populasi dan Sampel}

Populasi yang digunakan dalam penelitian ini adalah perusahaan manufaktur sub sektor automotive and allied product yang terdaftar di Bursa Efek Indonesia periode 2011-2017, yang merupakan anggota dari populasi yang bersumber dari Indonesia Capital Market Directory (ICMD) tahun 2015. Sedangkan dalam penetapan sampel penelitian dilakukan berdasarkan purposive sampling sehingga didapat hanya 10 perusahaan yang memenuhi ciri dan karakteristik yang sesuai.

Adapun kriteria atau pertimbangan pengambilan sampel yang digunakan penulis adalah:

1. Perusahaan telah terdaftar di Bursa Efek Indonesia (BEI)

2. Tidak delisting selama periode pengamatan tahun

3. Memberikan laporan keuangan secara periodik kepada Bursa Efek Indonesia dan dipublikasikan di website resmi BEI.

4. Perusahaan menyediakan data yang lengkap, sesuai dengan yang dibutuhkan dalam penelitian ini.

\section{Teknik Pengumpulan Data}

Dalam penelitian ini, penulis mengumpulkan data yang dibutuhkan dengan menggunakan teknik sebagai berikut:

1. Penelitian Lapangan

Dalam penelitian ini, penulis melakukan observasi pada obyek penelitian dengan tujuan untuk memperoleh data sekunder, yaitu dengan melakukan penelitian pada situs resmi Bursa Efek Indonesia yang beralamat di www.idx.co.id.

2. Studi Pustaka

Dalam penelitian ini, penulis melakukan studi kepustakaan dengan cara mempelajari, mengkaji dan menelaah literatur-literatur berupa buku, jurnal, berita, dan artikel blog di internet yang ada kaitanya dengan masalah yang diteliti.

\section{Hasil Penelitian dan Pembahasan}

\section{Uji Hipotesis}

Dalam penelitian ini, peneliti melakukan uji hipotesis dengan taraf kepercayaan 95\%, dengan syarat sebagai berikut:

1. Tolak hipotesis, jika nilai signifikansi hitung lebih besar atau sama dengan $\alpha=0.05$, yang berarti tidak terdapat pengaruh antara independen variabel terhadap dependen variabel.

2. Terima hipotesis, jika nilai signifikansi hitung lebih besar atau sama dengan $\alpha=0.05$, yang berarti terdapat pengaruh antara independen variabel terhadap dependen variabel.

Berdasakan pengolahan data, maka peneliti menemukan hasil sebagai berikut:

\section{Metode Analisis Data (Descriptive Statistic)}

Gambaran mengenai rata-rata, simpangan baku, nilai minimum dan nilai maksimum dari keseluruhan perusahaan berdasarkan masing-masing variabel dapat dilihat pada tabel statistik deskriptif dibawah ini : 


\begin{tabular}{|c|c|c|c|c|c|c|}
\hline \multicolumn{7}{|c|}{ Descriptive Statistics } \\
\hline & N & Minimum & Maximum & Mean & Std. Deviation & Variance \\
\hline DER & 70 & ,1332 & 14,3831 & 1,787609 & 2,5492414 & 6,499 \\
\hline Financia__istress & 70 & -0025 & 11,5170 & 3,365234 & 2,2540856 & 5,081 \\
\hline Growth_oppottunity & 70 & .9636 & 10,6775 & 2,096208 & 1,8413253 & 3,390 \\
\hline Liquidity & 70 &, 7366 & 5,0034 & 1,651130 &, 7821100 & .612 \\
\hline Firm_Size & 70 & 26,8251 & 33,3202 & 29,803889 & 1,6212885 & 2,629 \\
\hline Valid N (listwise) & 70 & & & & & \\
\hline
\end{tabular}

Tabel statistik deskriptif menyajikan ringkasan statistik dari variabel-variabel utama penelitian ini. Jumlah data penelitian adalah 70 observasi dengan sampel total penelitian ini terdiri dari 10 perusahaan yang sesuai dengan ciri dan karakter yang diinginkan penelitian dengan menggunakan satuan nilai mata uang IDR (Indonesia Rupiah) didalam laporan keuangan tahunannnya.

\section{Model Logistic Regression}

Menilai kelayakan model regresi dilakukan dengan menganalisis nilai signifikan pada tabel Hosmer and Lemeshow Goodness of fit test. Menurut Santoso (2014:219), model regresi binary layak dipakai apabila tidak ada perbedaan yang nyata antara klasifikasi yang diprediksi dengan klasifikasi yang diamati. Hasil uji hal tersebut disajikan pada table Hosmer and Lemeshow test sebagai berikut :

\section{Tabel 2}

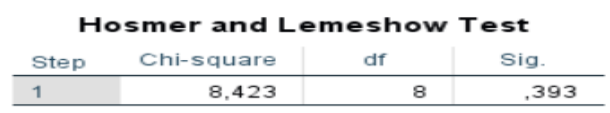

Dasar pengambilan keputusan menurut Santoso (2014:219), yaitu nilai goodness of fit yang diukur dengan nilai Chi-Square pada tabel Hosmer and Lemeshowmenyatakan :

- Jika probabilitas $>0,05 \mathrm{H} 0$ diterima

- Jika probabilitas <0,05 Ho ditolak

Pada tabel Hosmer and Lemeshow test bagian sig. adalah 0,393 >0,05, maka $\mathrm{H} 0$ diterima. Hal ini berarti model regresi binary layak dipakai untuk analisis selanjutnya karena tidak ada perbedaan yang nyata antara klasifikasi yang diprediksi dengan klasifikasi yang diamati.

\section{Menilai Keseluruhan Model}

\section{Tabel 3}

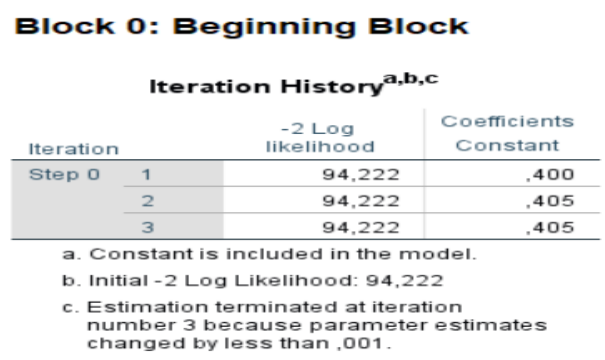

Block 1: Method = Enter

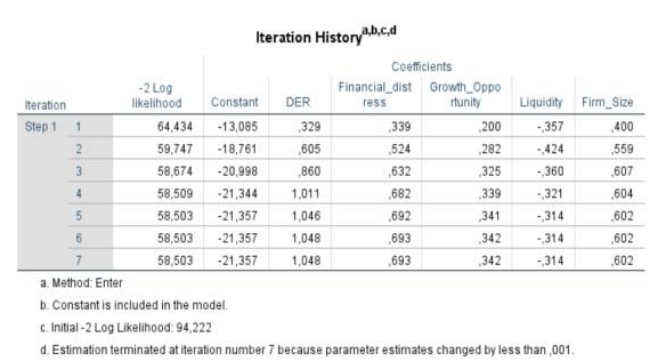

Berdasarkan tabel Block 0 : Beginning Block dapat terlihat bahwa hasil dari iteration block 0 kolom -2 Log Likelihood (-2LL) sebesar 94,222 sedangkan dalam iteration block 1 kolom 2LL menunjukkan penurunan nilai menjadi 58,503 maka hal ini memiliki arti menurut Santoso (2014:220) yaitu "Likelihood pada regresi binary mirip dengan pengertian 'sum squared error' pada model regresi, menunjukkan model regresi yang lebih baik." 
Tabel 4

\begin{tabular}{|l|l|}
\hline \multicolumn{1}{|c|}{ Block } & Nilai Overall Percentage \\
\hline Block 0 & 60,0 \\
\hline Block 1 & 84,3 \\
\hline
\end{tabular}

Selain itu juga, berdasarkan hasil dari Classification Tablestep 0 dan step 1 yang terangkum pada tabel Overall Percentage (Tabel 4) diatas dapat dilihat hasil block 1 menyatakan nilai lebih besar daripada hasil block 0. Sebesar 84,3 lebih besar daripada 60,0 artinya bahwa model regresi dengan estimator pada variabel independen adalah tepat dalam mengestimasikan pengaruh variabel independen terhadap keputusan hedging.

\section{Menilai Model Summary}

\section{Tabel 5}

\begin{tabular}{|c|c|c|c|}
\hline \multicolumn{4}{|c|}{ Model Summary } \\
\hline Step & $\begin{array}{l}-2 \log \\
\text { likelihood }\end{array}$ & $\begin{array}{c}\text { Cox \& Snell R } \\
\text { Square }\end{array}$ & $\begin{array}{c}\text { Nagelkerke } R \\
\text { Square }\end{array}$ \\
\hline 1 & $58,503^{\mathrm{a}}$ & .400 & .540 \\
\hline
\end{tabular}

Tabel Model Summary diatas menunjukkan kemampuan variabel independen dalam menjelaskan variabel dependennya. Pada kolom Nagelkerke $R$ Square memiliki hasil sebesar 0,540 dan kolom Cox \& Snell $R$ Square menghasilkan output sebesar 0,400 yang artinya adalah kemampuan setiap variabel independen penelitian ini yaitu DER, financial distress, growth opportunity, liquidity dan firm size dalam menjelaskan variabel dependennya yaitu hedging adalah hanya sebesar 0,400 atau $40 \%$ yang mana terdapat sebesar $60 \%$ sisanya mampu dijelaskan oleh faktor lain diluar faktor independen yang digunakan dalam penelitian ini yang juga mampu menjelaskan variabel dependen hedging tersebut.

\section{Pembahasan}

\section{Tabel 6}

\begin{tabular}{|c|c|c|c|c|c|c|c|}
\hline \multicolumn{8}{|c|}{ Variables in the Equation } \\
\hline & & $B$ & S.E. & Wald & df & Sig. & $\operatorname{Exp}(B)$ \\
\hline \multirow[t]{6}{*}{ Step $1^{3}$} & DER & 1,048 & .499 & 4,413 & 1 &, 036 & 2,851 \\
\hline & Financial_distress & 693 & 280 & 6,127 & 1 &, 013 & 1,999 \\
\hline & Growth_Opportunity &, 342 & .227 & 2,270 & 1 &, 132 & 1,407 \\
\hline & Liquidity & -314 & .633 & .246 & 1 &, 620 &, 731 \\
\hline & Firm_Size &, 602 &, 259 & 5,411 & 1 &, 020 & 1,825 \\
\hline & Constant & $-21,357$ & 8,251 & 6,700 & 1 &, 010 & 000 \\
\hline
\end{tabular}

Berdasarkan pada hasil hipotesis penelitian yang dijabarkan pada tabel variables in the equation pada kolom sign. (signifikan), terlihat angka untuk variabel DER, financial distress dan firm size berada dibawah syarat pengambilan keputusan berdasarkan probabilitas yaitu 0,05 (5\%). Variabel DER menunjukkan nilai koefisien B positif sebesar 1,048 dengan probabilitas atau signifikansi sebesar 0,036 berada dibawah syarat pengambilan keputusan berdasarkan probabilitas yaitu 0,05 , lalu variabel financial distress menunjukkan nilai koefisien B positif sebesar 0,693 dengan probabilitas atau signifikansi sebesar 0,013 berada dibawah syarat pengambilan keputusan berdasarkan probabilitas yaitu $0,05(5 \%)$ dan terakhir variabel firm size menunjukkan nilai koefisien $\mathrm{B}$ positif sebesar 0,602 dengan probabilitas atau signifikansi sebesar 0,020 berada dibawah syarat pengambilan keputusan berdasarkan probabilitas yaitu $0,05(5 \%)$ maka ketiga variabel diatas menunjukkan arti bahwa Hoditolak atau sama dengan H1 diterima. Dengan demikian dapat disimpulkan bahwa variabel DER, financial distress dan firm size, secara masing-masing berpengaruh signifikan terhadap penggunaan instrumen derivatif sebagai pengambilan keputusan hedging. 
Kesimpulan dari hasil koefisien regresi berdasarkan hipotesis penelitian diatas adalah pengujian model regresi logistik binary ini pada tingkat signifikan yang dipakai yaitu 0,05 , yang memiliki arti bahwa variabel DER, financial distress dan firm size sangat baik karena tingkat kesalahan atau eror sangat kecil atau sangat sedikit yaitu hanya 5\% saja dengan bentuk persamaan logistik regresi yakni :

$\operatorname{L\eta } \frac{\rho}{1-\rho}=-21,357+1,048$ DER $+0,693$ financial distress $+0,602$ firm size atau, Hedging $=-21,357+1,048$ DER $+0,693$ financial distress $+0,602$ firm size

\section{Keterangan :}

- Nilai konstanta: nilai konstanta negatif artinya hedging memang sangat penting untuk diterapkan dalam perusahaan. Variabel DER, financial distress dan firm size sangat membutuhkan penggunaan hedging.

- Koefisien regresi variabel DER: 1,048 , artinya jika variabel independen lain nilainya tetap dan DER mengalami kenaikan $1 \%$, maka hedging akan mengalami peningkatan sebesar 1,048. Koefisien bernilai positif artinya terjadi hubungan positif antara DER dengan keputusan hedging, semakin naik DER maka semakin meningkatkan keputusan hedging.

- Koefisien regresi variabel financial distress: 0,693, artinya jika variabel independen lain nilainya tetap dan financial distress mengalami kenaikan 1\%, maka hedging akan mengalami peningkatan sebesar 0,693. Koefisien bernilai positif artinya terjadi hubungan positif antara financial distress dengan keputusan hedging, semakin naik financial distress maka semakin meningkatkan keputusan hedging.
- Koefisien regresi variabel firm size : 0,602, artinya jika variabel independen lain nilainya tetap dan firm size mengalami kenaikan $1 \%$, maka hedging akan mengalami peningkatan sebesar 0,602 . Koefisien bernilai positif artinya terjadi hubungan positif antara firm size dengan keputusan hedging, semakin naik firm size maka semakin meningkatkan keputusan hedging.

\section{Hasil Penelitian}

1. Pengaruh debt equity ratio (DER) terhadap keputusan hedging

Variabel DER berpengaruh positif signifikan terhadap penggunaan instrumen derivatif sebagai pengambilan keputusan hedging karena memiliki hasil olahan SPSS yang berada dibawah 0,05 yaitu 0,036. Hasil penelitian ini mendukung penelitian Putro (2012) dan Zulfiana (2014) dan teori yang telah dibuat bahwa "semakin tinggi tingkat hutang atau debt equity ratio maka akan semakin besar pengambilan keputusan hedging yang dilakukan untuk mengurangi dampak buruk dari risiko hutang".

Hal ini dapat terjadi karena semakin besar tingkat hutang suatu perusahaan maka risiko yang ditanggung oleh perusahaan pun semakin besar. Risiko seperti tidak mampu membayar kewajiban (hutang) jangka pendek maupun jangka panjang. Oleh sebab itu, dengan pengambilan keputusan hedging yang dilakukan perusahaan dapat meminimalisir atau mencover risiko debt to equity pada perusahaan.

2. Pengaruh financial distress terhadap keputusan hedging

Variabel financial distress berpengaruh positif signifikan 
terhadap penggunaan instrumen derivatif sebagai pengambilan keputusan hedging karena memiliki hasil olahan SPSS yang berada dibawah 0,05 yaitu 0,013 . Hal ini bertentangan dengan teori terdahulu yang menyatakan bahwa pengambilan keputusan hedging dilakukan hanya pada saat perusahaan mengalami risiko kesulitan keuangan (financial distress) saja, sedangkan pada saat perusahaan tidak mengalami kesulitan keuangan maka tidak mengambil keputusan hedging. Keputusan hedging ini dilakukan untuk mengatasi masalah yang terjadi akibat kesulitan keuangan (financial distress). Dapat diartikan bahwa keputusan hedging yang dilakukan perusahaan bukan untuk mengantisipasi risiko tetapi dilakukan untuk mengatasi masalah akibat kesulitan keuangan.

Apabila melihat hasil dari pengolahan data peneliti, financial distress justru berpengaruh positif signifikan terhadap keputusan hedging maka dapat di interpretasikan bahwa dalam periode 2011 hingga 2017, perusahaan manufaktur sub sektor automotive and allied products justru berupaya mengantisipasi risiko dimana sebelum permasalahan kesulitan keuangan terjadi. Perusahaan sampel menggunakan hedging juga ketika perusahaan tidak mengalami kesulitan keuangan, terlihat dari positifnya hasil dari uji model regresi. Dapat diambil kesimpulan jika semakin berkembangnya jaman,perusahaan semakin sadar untuk melakukan antisipasi terhadap risiko.
3. Pengaruh growth opportunity terhadap keputusan hedging Variabel growth opportunity tidak berpengaruh terhadap penggunaan instrumen derivatif sebagai pengambilan keputusan hedging karena memiliki hasil olahan SPSS yang berada diatas 0,05 yaitu 0,132 . Hal ini bertentangan dengan hasil penelitian acuan yaitu Putro (2012) dan juga hasil penelitian lainnya yaitu Subagja (2015) yang menyatakan bahwa variabel growth opportunity berpengaruh positif signifikan terhadap pengambilan keputusan hedging. Namun hal ini mendukung penelitian Zulfiana (2014) yang menyatakan bahwa variabel growth opportunity tidak berpengaruh terhadap pengambilan keputusan hedging.

\begin{tabular}{lcr}
\multicolumn{2}{c}{ Menurut } & Zulfina \\
(2014:96) & yang & melakukan \\
penelitian & di & perbankan \\
menyatakan & bahwa hal ini \\
dikarenakan & perusahaan dalam \\
mengatasi & pertumbuhan laba
\end{tabular}
perusahaan agar semakin tinggi menggunakan berbagai cara yaitu salah satunya dengan menggencarkan penjualan produk baik dari produk giro dan tabungan (CASA) perbankan dan peningkatan penyaluran kredit. Oleh sebab itu, variabel pertumbuhan laba perusahaan tidak mempengaruhi keputusan hedging yang dilakukan bank konvensional.

Dalam penelitian ini, yang mana menggunakan objek perusahaan manufaktur sub sektor automotive and allied products, memiliki hasil bahwa variabel growth opportunity tidak berpengaruh tehadap keputusan hedging dikarenakan perusahaan dalam mengatasi pertumbuhan 
laba perusahaan agar semakin tinggi menggunakan berbagai cara lain yaitu salah satu cara dengan menggencarkan penjualan produkproduk automotive, meningkatkan kinerja pemasaran dan sebagainya. Maka dari itu, variabel growth opportunity tidak mempengaruhi keputusan hedging

4. Pengaruh liquidity terhadap keputusan hedging

Variabel liquidity tidak berpengaruh terhadap penggunaan instrumen derivatif sebagai pengambilan keputusan hedging karena memiliki hasil olahan SPSS yang berada diatas 0,05 yaitu 0,620. Hal ini sejalan dengan hasil penelitian acuan sebelumnya yang dilakukan oleh Putro (2012) dan peneliti lainnya yaitu Subagja (2014) bahwa variabel liquidity tidak berpengaruh terhadap pengambilan keputusan hedging.

5. Pengaruh firm size terhadap keputusan hedging

Variabel firm size berpengaruh positif signifikan terhadap penggunaan instrumen derivatif sebagai pengambilan keputusan hedging karena memiliki hasil olahan SPSS yang berada dibawah 0,05 yaitu 0,020 . Hal ini terjadi dikarenakan perusahaan yang berukuran yang besar memiliki aktivitas operasional yang luas dan lebih berisiko karena adanya kemungkinan besar untuk bertransaksi ke berbagai negara akan melibatkan beberapa mata uang berbeda. Dalam kegiatannya akan terdapat eksposur transaksi karena fluktuatifnya nilai tukar mata uang asing.

\section{Simpulan dan Saran}

\section{Simpulan}

1. Debt to equity ratio (DER) mempunyai pengaruh yang signifikan positif terhadap pengambilan keputusan hedging pada perusahaan manufaktur sub sektor automotive and allied products pada periode penelitian 2011 hingga 2017. Maka sebagai kesimpulannya adalah semakin tinggi tingkat DER maka akan semakin besar pengambilan keputusan hedging yang akan dilakukan perusahaan untuk mengurangi dampak buruk dari risiko hutang. Karena semakin besar tingkat hutang suatu perusahaan maka tingkat risiko sulit bayar kewajiban akan semakin meningkat.

2. Financial distress mempunyai pengaruh yang signifikan positif terhadap pengambilan keputusan hedging pada perusahaan manufaktur sub sektor automotive and allied products pada periode penelitian 2011 hingga 2017. Maka sebagai kesimpulannya adalah semakin maraknya arus globalisasi, semakin bergantinya tahun, perusahaan merasa semakin penting menggunakan hedging dalam meminimalisir risiko yang akan terjadi. Terlihat dari nilai positif signifikan yang mana berarti bahwa perusahaan sampel berupaya mengantisipasi risiko dimana sebelum permasalahan kesulitan keuangan (financial distress) terjadi.

3. Growth opportunity tidak mempunyai pengaruh yang signifikan terhadap keputusan hedging pada perusahaan manufaktur sub sektor automotive and allied products pada periode penelitian 2011 hingga 2017. 
Alasannya adalah karena cara untuk mengatasi tingkat growth opportunity, bukan hanya dengan menggunakan hedging. Tetapi banyak faktor yang dapat membuat tingkat growth opportunity perusahaan meningkat sebagai contoh adalah menggencarkan penjualan produk-produk automotive, meningkatkan kinerja pemasaran dalam perusahaan dan sebagainya.

4. Liquidity tidak mempunyai pengaruh yang signifikan terhadap keputusan hedging pada perusahaan manufaktur sub sektor automotive and allied products pada periode penelitian 2011 hingga 2017. Alasannya adalah perusahaan manufaktur tidak terlalu rentan hubungannya dengan likuiditas jika dibandingkan dengan perusahaaan yang bergerak di bidang keuangan seperti perbankan, asuransi dan sebagainya. Maka dari itu tingkat liquidity dalam penelitian ini tidak memiliki pengaruh terhadap keputusan hedging.

5. Firm size mempunyai pengaruh yang signifikan positif terhadap pengambilan keputusan hedging pada perusahaan manufaktur sub sektor automotive and allied products pada periode penelitian 2011 hingga 2017. Sebagai kesimpulannya semakin besar ukuran perusahaan, risiko yang akan diterima oleh perusahaan akan semakin besar, maka perlu dilakukan antisipasi risiko salah satunya dengan menggunakan hedging. Karena perusahaan dengan ukuran perusahaan yang besar akan memiliki sistem manajemen risiko yang sangat terstruktur dibandingkan dengan perusahaan dengan ukuran perusahaan yang kecil.

\section{Saran}

Berdasarkan hasil penelitian, peneliti mengungkapkan saran sebagai berikut:

\section{Bagi Manajerial}

Berdasarkan hasil penelitian dengan menggunakan objek perusahaan manufaktur sub sektor automotive and allied produtcs periode 2006-2017 didapatkan hasil bahwa variabel DER, financial distress dan firm size berpengaruh signifikan terhadap keputusan hedging, sedangkan variabel growth opportunity dan liquidity tidak berpengaruh signifikan terhadap keputusan hedging. Maka disarankan bagi perusahaan yang akan menggunakan instrumen derivatif sebagai pengambilan keputusan hedging diharapkan untuk memperhatikan informasi internal perusahaan yang bersangkutan yakni debt to equity ratio (DER), financial distress dan firm size. Pentingnya memperhatikan variabelvariabel tersebut dikarenakan perusahaan diharapkan dapat mencegah risiko yang berasal dari eksposur valuta asing yang seharusnya dapat dialihkan oleh penggunaan instrumen derivatif sebagai sarana hedging, dan mencegah perusahaan untuk mengeluarkan biaya derivatif dengan tidak memberikan manfaat yang diharapkan.

\section{Bagi Investor}

Bagi investor yang akan melakukan investasi ke dalam perusahaan manufaktur yang terdaftar di Bursa Efek Indonesia dapat memperhitungkan terlebih dahulu variabel DER, financial distress dan firm size yang dimiliki perusahaan tersebut. Bila nilai yang ditunjukkan oleh variabelvariabel tersebut menunjukkan angka yang relatif tinggi dibandingkan dengan perusahaan lainnya, namun perusahaan tersebut belum melakukan aktivitas hedging maka dapat disimpulkan bahwa perusahaan tersebut memiliki risiko yang cukup besar terhadap eksposur valuta asing.

\section{Bagi Penelitian yang Akan Datang}

Bagi penelitian selanjutnya dapat menambahkan variabel internal lain dalam perusahaan seperti jumlah pajak 
penghasilan, arus kas, kepemilikan manajerial, tingkat leverage, tingkat suku bunga dan sebagainya sehingga model penelitian yang dihasilkan memiliki ketepatan lebih tinggi. Disamping itu, dapat menggunakan rentang waktu yang lebih panjang, sehingga mampu menjelaskan keseluruhan variabel yang diteliti. Juga, dapat menggunakan variabel eksternal perusahaan seperti risiko bisnis, stabilitas keamanan, kebijakan politik, regulasi pemerintah, perkembangan pasar, dan pasar modal, sehingga hasil penelitian lebih bersifat menyeluruh.

\section{Daftar Pustaka}

Brealey, Richard A., Stewart C. Myers dan Alan J. Marcus. 2012. Fundamentals of Corporate Finance. 7th edition. New York:Mc Graw Hill

Hosmer, David W. and Stanley Lemeshow. 2011. Applied Logistic Regression. New York: John Wiley \& Sons.

Kasmir. 2008. Analisis Laporan Keuangan. Jakarta:Raja Grafindo Persada

Myers, S., 1977. The determinants of corporate borrowing. Journal of Financial Economics 5, 147-175.

Nance, D.R., Smith Jr., C.W., Smithson, C.W. 1993. On the determinants of corporate hedging. Journal of Finance 48.267-284.

Pramborg, Bengt. 2005. Foreign Exchange Risk Management by Swedish and Korean Nonfinancial Firms : A Comparative Survey. Finance Journal 13 : Stockholm University School of Business Sweden. Pp. 343-366

Putro, Septama Hardanto. 2012. "Analisis Faktor Yang Mempengaruhi Penggunaan Instrumen Derivatif Sebagai Pengambilan Keputusan Hedging (Studi Kasus Pada Perusahaan Automotive and Allied
Products Yang Terdaftar di BEI Periode 2006-2010)". Semarang. Diponegoro Business Review. Vol. 1. No. 1. PP. 1-11.

Santoso, Singgih. (2014a). Statistik Multivariat Edisi Revisi. Jakarta:PT Elex Media

Komputindo.

Santoso, Singgih. (2017b). Menguasai Statistik dengan SPSS 24. Jakarta:PT Elex Media Komputindo.

Smith, Clifford W., and René Stulz, 1985, The determinants of firms' hedging policies, Journal of Financial and Quantitative Analysis 20, 391-405.

Subagya, Ricki. 2015. Analisis FaktorFaktor Yang Mempengaruhi Kebijakan Hedging Dengan Menggunakan Instrumen Derivatif Valuta Asing (Studi Empiris Pada Perusahaan Non-Finansial Yang Terdaftar di BEI 2010-2014). Semarang.

Sundjaja, Ridwan, Inge Barlian, Dharma Sundjaja. 2012. Manajemen Keuangan 1. Edisi 8. Cetakan ke-2. Bandung

Wiyono, Gendro dan Hadri Kusuma. 2017. Manajemen Keuangan Lanjutan, Edisi Pertama. Yogyakarta :UPP STIM YKPN.

Zulfiana, Ika. 2014. Analisis Faktor Internal dan Faktor Eksternal yang Mempengaruhi Penggunaan Instrumen Derivatif sebagai Pengambilan Keputusan Hedging (Studi Kasus pada Bank Konvensional yang terdaftar di BEI Periode 2008-2012)

\section{Internet:}

https://www.cnnindonesia.com/ekonomi/20 180327105823-78-

286176/mengatur-irama-rupiahdan-suku-bunga-acuan-di-tahunpolitik

www.idx.co.id. 